\title{
Uptake of Triiodothyroacetic Acid and Its Effect on Thyrotropin Secretion in Cultured Anterior Pituitary Cells*
}

\author{
M. E. EVERTS†, T. J. VISSER, E. P. C. M. MOERINGS, R. DOCIER, H. VAN TOOR,
} A. M. P. TEMPELAARS, M. DE JONG, E. P. KRENNING, AND G. HENNEMANN

Departments of Internal and Nuclear Medicine, Erasmus University Medical School, 3000 DR Rotterdam, The Netherlands

\begin{abstract}
The uptake of $\left[{ }^{125} \mathrm{I}\right]$ triiodothyroacetic acid $\left(\left[{ }^{125} \mathrm{I}\right]\right.$ Triac) in anterior pituitary cells was investigated and compared with that of $\left[{ }^{125} I\right] \mathrm{T}_{3}$. Furthermore, the effects of Triac, $T_{3}$, and $T_{4}$ on $\mathrm{TSH}$ release were compared. Cells isolated from adult male $\mathrm{W}$ istar rats were cultured for 3 days in medium with $10 \%$ fetal calf serum. Uptake was measured at $37 \mathrm{C}$ with [ $\left.{ }^{125} \mathrm{I}\right]$ Triac $(100,000 \mathrm{cpm} ; 120 \mathrm{pM})$ or $\left[{ }^{125} \mathrm{I}\right] \mathrm{T}_{3}(50,000 \mathrm{cpm} ; 50$ $\mathrm{pM}$ ) in medium with $0.5 \% \mathrm{BSA}$. In this medium, the ratio of the free fractions of Triac, $\mathrm{T}_{3}$, and $\mathrm{T}_{4}$ was 1:8:1. Exposure of cells to $100 \mathrm{nM}$ TRH for $2 \mathrm{~h}$ stimulated TSH release by $80-110 \%(P<0.001)$. Comparing total hormone levels ( $1 \mathrm{nM}$ to $1 \mu \mathrm{M}$ ), Triac and $\mathrm{T}_{3}$ were equally effective in reducing this response, and both were 10 -fold more effective than $T_{4}$. The time course $\left(15 \mathrm{~min}\right.$ to $4 \mathrm{~h}$ ) of $\left[{ }^{125} \mathrm{I}\right] \mathrm{T}$ riac uptake was similar to that of $\left[{ }^{125} \mathrm{I}\right] \mathrm{T}_{3}$, showing equilibrium after $1 \mathrm{~h}$. Unlabeled Triac $(1 \mu \mathrm{M})$ reduced the uptake of $\left[{ }^{125} \mathrm{I}\right]$ Triac and $\left[{ }^{125} \mathrm{I}\right] \mathrm{T}_{3}$ at all time intervals. Expressed per pM free hormone, the cellular and nuclear uptake of $\left[{ }^{125} \mathrm{I}\right]$ Triac were twice those of $\left[{ }^{125} \mathrm{I}\right] \mathrm{T}_{3}$. The 15 -min uptake of
\end{abstract}

$\left.{ }^{[25} \mathrm{I}\right]$ Triac was reduced by incubation with $10 \mathrm{nM}$ unlabeled Triac $(35 \%$; $P<0.001$ ). Maximum inhibition (56\%; $P<0.001$ ) was found with 10 $\mu \mathrm{M}$ Triac. A similar effect was seen with $10 \mu \mathrm{M} \mathrm{T}_{3}, \mathrm{~T}_{4}$, or $3,3^{\prime}, 5,5^{\prime}$ tetraiodothyroacetic acid. Preincubation $(30 \mathrm{~min})$ and incubation (15 min) with $10 \mu \mathrm{M}$ oligomycin reduced the cellular ATP content by $51 \%$ $(P<0.001),\left[{ }^{125} \mathrm{I}\right] \mathrm{T}_{3}$ uptake by $77 \%(P<0.001)$, and $\left[{ }^{125} \mathrm{I}\right]$ Triac uptake by only $25 \%(P<0.001)$. The temperature dependence of $\left[{ }^{125} \mathrm{I}\right]$ Triac and $\left.{ }^{125} \mathrm{I}\right] \mathrm{T}_{3}$ uptake was the same. Preincubation and incubation with $10 \mu \mathrm{M}$ monensin (reduces the $\mathrm{Na}^{+}$gradient) or $10 \mu \mathrm{M}$ monodansylcadaverine (inhibits receptor-mediated endocytosis) reduced $15-\min \left[{ }^{125} \mathrm{I}\right]$ Triac uptake by $15 \%(P<0.005)$ and $19 \%(P<0.005)$, respectively. The data show that 1) Triac, on the basis of the free hormone concentration, is more potent than $\mathrm{T}_{3}$ or $\mathrm{T}_{4}$ in suppressing $\mathrm{TSH}$ secretion; and 2) the rapid uptake of $\left.{ }^{125} \mathrm{I}\right]$ Triac by the anterior pituitary occurs by a carrier-mediated mechanism that is only partially dependent on ATP or the $\mathrm{Na}^{+}$gradient. (Endocrinology 135: 2700 2707, 1994)
$\mathrm{T}$ HE METABOLISM of $\mathrm{T}_{3}$ occurs by three pathways: deiodination, conjugation, and side-chain alteration. Whereas $50-60 \%$ of $T_{3}$ in humans is deiodinated to $3,3^{\prime}$ diiodothyronine (1), alteration of the alanine side-chain, resulting in the production of 3,3',5-triiodothyroacetic acid (Triac), may account for around $14 \%$ of $\mathrm{T}_{3}$ metabolism in man (2). However, under pathological conditions, as, for example, fasting, Triac production is substantially increased $(3,4)$. Furthermore, these researchers suggested that Triac might be of importance for the suppression of TSH secretion in fasting, which occurs despite low plasma $T_{3}$ and $T_{4}$ levels. Also, under conditions other than fasting, characterized by low plasma $\mathrm{TSH}, \mathrm{T}_{3}$, and $\mathrm{T}_{4}$, Triac might play a role in the suppression of TSH secretion (5).

In euthyroid and hypothyroid subjects, administration of Triac suppresses basal TSH secretion (6-8) as well as the TSH response to TRH $(6,9)$. Furthermore, Triac is used in the treatment of patients with thyroid cancer $(10,11)$ and

Received May 30, 1994.

Address all correspondence and requests for reprints to: Maria E. Everts, Ph.D., Department of Internal Medicine III, Erasmus University Medical School, Room Bd 240, Postbox 1738, 3000 DR Rotterdam, The Netherlands.

* This work was supported by the Trustfonds of the Erasmus University Rotterdam (The Netherlands).

† Recipient of a fellowship from the Royal Netherlands Academy of Arts and Sciences. generalized resistance to thyroid hormones $(12,13)$. However, the question of whether the effects of Triac are specific for the pituitary gland has not been definitively answered $(8,9,11,14)$.

Early in vitro studies showed that $\mathrm{T}_{3}$ and Triac were equally potent in the suppression of TSH production and displacement of $\left[{ }^{125} \mathrm{I}\right] \mathrm{T}_{3}$ from the nuclear binding sites in mouse thyrotropic tumor cells (15). In rat pituitary fragments superfused with BSA-containing medium, both $0.1 \mu \mathrm{M}$ Triac and $0.1 \mu \mathrm{M} \mathrm{T} \mathrm{T}_{3}$ reduced the TRH-induced TSH release by around 25\% (16).

Previously, we reported evidence for carrier-mediated uptake of $T_{3}$ and $T_{4}$ in cultured anterior pituitary cells of euthyroid rats $(17,18)$. Moreover, $T_{3}$ and $T_{4}$ seem to share the same carrier in the pituitary $(18,19)$. The purpose of the present work was to study 1) the effect of Triac, compared to those of $\mathrm{T}_{3}$ and $\mathrm{T}_{4}$, on basal and TRH-induced TSH release; and 2) the mechanism of uptake of $\left[{ }^{125} \mathrm{I}\right]$ Triac into cultured anterior pituitary cells. Furthermore, we questioned whether the uptake of $\left.{ }^{125} \mathrm{I}\right]$ Triac occurred by the same transport mechanism as that described for $T_{3}$ and $T_{4}$.

\section{Materials and Methods}

\section{Materials}

All solutions used for cell isolation and cell culture were obtained from Gibco Europe (Breda, The Netherlands), with the exception of 
human serum albumin (Central Laboratory of the Red Cross Blood Transfusion Service, Amsterdam, The Netherlands), dispase (grade II; Boehringer, Mannheim, Germany), absorbed fetal calf serum (Flow Laboratories, Irvine, Scotland), and Fungizone (Bristol-Myers Squibb, Woerden, The Netherlands). Culture dishes (48 wells) were obtained from Costar (Cambridge, MA). All iodothyronines, 3,5-diiodothyroacetic acid 'Triac, and 3,3',5,5'-tetraiodothyroacetic acid ('letrac), were obtained from Henning Berlin (Berlin, Germany). Piperazine- $N, N^{\prime}$-bis- $[2-$ ethane sulfonic acid], HEPES, $N, N$-bis-[2-hydroxyethyl]2-aminoethane sulfonic acid, BSA (fraction V), monensin, oligomycin, and monodansylcadaverine (MDC) were purchased from Sigma Chemical Co. (St Louis, MO). TRH was obtained from Hoechst (Frankfurt am Main, Germany). $\left[3^{\prime}-{ }^{125} \mathrm{ITT}_{3}(3070 \mu \mathrm{Ci} / \mu \mathrm{g})\right.$ and carrier-free $\mathrm{Na}^{125} \mathrm{I}$ were purchased from Amersham International (Aylesbury, United Kingdom). [ $3^{\prime}$ ${ }^{125}$ I]Triac $(2730 \mu \mathrm{Ci} / \mu \mathrm{g})$ was prepared from $\mathrm{Na}^{125}$ I and 3,5-diiodothyroacetic acid using the chloramine-T method (20). Sephadex LH-20 and G-25 were obtained from Pharmacia (Uppsala, Sweden). All other reagents were of the highest purity available.

\section{Animals}

All experiments were performed using male Wistar rats, weighing $220-250 \mathrm{~g}$. The animals had free access to food and water and were kept in a controlled environment $(21 \mathrm{C})$ with constant day length (12 h).

\section{Cell culture}

Animals (12-18 for each experiment) were killed between 0900-0930 $\mathrm{h}$ by decapitation. The pituitary glands were removed within $5 \mathrm{~min}$, the neurointermediate lobe was discarded, and the anterior lobes were collected in calcium- and magnesium-free Hanks' Balanced Salt Solution supplemented with $10 \mathrm{~g}$ /liter human serum albumin, penicillin $\left(10^{5} \mathrm{U} /\right.$ liter), Fungizone $(0.5 \mathrm{mg} /$ liter $)$, and sodium bicarbonate $(0.4 \mathrm{~g} / \mathrm{liter})$. Anterior pituitary cells were dissociated with dispase (final concentration, $2.4 \times 10^{3} \mathrm{U} /$ liter), as described in detail previously (21). From each pituitary, around $1.5 \times 10^{6}$ cells were obtained, and the viability of the cells, determined by trypan blue exclusion, was greater than $90 \%$.

The cells were cultured at $37 \mathrm{C}$ in a water-jacketed incubator with $5 \% \mathrm{CO}_{2}$ at a density of $5-8 \times 10^{5}$ cells/well in 48 -well culture dishes. The cells had attached to the wells after 2 days of culture. On day 3 , the cells were used for experiments. The culture medium consisted of Minimum Essential Medium with Earle's salts supplemented with nonessential amino acids, sodium pyruvate (1 mmol/liter), $10 \%$ fetal calf serum (in experiments for Table 1, 10\% absorbed fetal calf serum), penicillin $\left(10^{5} \mathrm{U} /\right.$ liter $)$, Fungizone $(0.5 \mathrm{mg} / \mathrm{liter})$, L-glutamine $(2 \mathrm{mmol} /$ liter), and sodium bicarbonate $(2.2 \mathrm{~g} / \mathrm{liter})$, pH $7.4(21,22)$.

\section{Cellular uptake of $\left[{ }^{125} I\right]$ Triac and $\left.{ }^{25} I\right] T_{3}$}

After removal of the culture medium, cells were preincubated with $0.5 \mathrm{ml}$ incubation medium. The incubation medium was identical to the culture medium, except that the fetal calf serum was replaced by $0.1 \%$ or $0.5 \%$ BSA. Preincubation was carried out for $30 \mathrm{~min}$ at $37 \mathrm{C}$ in the absence or presence of $10 \mu \mathrm{M}$ oligomycine, MDC, or monensin. The medium was removed after preincubation, and incubation was started with $0.25 \mathrm{ml}$ medium containing the same additions as those described above, $10 \mathrm{nM}$ to $10 \mu \mathrm{M}$ Triac, or $10 \mu \mathrm{M} \mathrm{T}_{3}, \mathrm{~T}_{4}$, or Tetrac and in all cases $\left.{ }^{125} \mathrm{I}\right]$ Triac $(100,000-200,000 \mathrm{cpm} ; 120-240 \mathrm{pM})$ or $\left[{ }^{125} \mathrm{I}\right] \mathrm{T}_{3}(50,000 \mathrm{cpm}$; $50 \mathrm{pM})$

Incubations lasting for more than $1 \mathrm{~h}$ were performed at $37 \mathrm{C}$ in humidified air with $5 \% \mathrm{CO}_{2}$. Incubations of shorter duration took place in a $37 \mathrm{C}$ incubation chamber on a rotating device without $\mathrm{CO}_{2}$. Therefore, the $\mathrm{NaHCO}_{3}$ in the culture medium was replaced by an equimolar amount of HEPES $(8.9 \mathrm{~mm})$, piperazine- $N, N^{\prime}$-bis- $\{2$-ethane sulfonic acid] $(10.6 \mathrm{~mm})$ and $N, N$-bis-[2-hydroxyethyl]2-aminoethane sulfonic acid (11.2 $\mathrm{mm})$.

After incubation, the medium was removed, and the cells were washed with $1-\mathrm{ml}$ volumes of ice-cold saline to remove tracer not bound to the cells. Cells were dissolved in $1 \mathrm{ml} 0.1 \mathrm{~N} \mathrm{NaOH}$ and counted for ${ }^{125} \mathrm{I}$ activity in a 16 -channel $\gamma$-counter (NE 1600, Nuclear Enterprises,
Edinburgh, Scotland). The amount of $\left[{ }^{125} \mathrm{I}\right] \mathrm{Triac}$ or $\left[{ }^{125} \mathrm{I}\right] \mathrm{T}_{3}$ taken up was expressed as a percentage of the added radioactivity (percentage of the dose). The same procedure was applied to incubations without cells (blanks). All results were corrected for the amount of radioactivity retained in the wells without cells.

\section{Nuclear binding of [ $\left.{ }^{25} I\right]$ Triac and $\left[{ }^{125} I\right] T_{3}$}

After incubation, cells were washed once with ice-cold saline $\mathbf{0 . 9 \%}$ $\mathrm{NaCl}$ ). The cells were harvested from the wells with a rubber policeman in $1 \mathrm{ml}$ PBS (on ice) and counted for $30 \mathrm{sec}$. Isotope uptake, calculated as a percentage of the dose with this method, gave similar values for the cellular radioactivity as the usual procedure with $0.1 \mathrm{~N} \mathrm{NaOH}$. All of the following procedures were performed on ice. A cell pellet was obtained after centrifugation $(300 \times 8 ; 4 \mathrm{C} ; 7 \mathrm{~min})$, counted $(30 \mathrm{sec})$, and solubilized in $1 \mathrm{ml}$ PBS containing $0.5 \%$ Triton X-100, as previously described (23). After 2 min of continuous vortexing, nuclei were spun down $(900 \times g ; 4 \mathrm{C} ; 5 \mathrm{~min})$ and washed once with $1 \mathrm{ml}$ PBS containing $0.5 \%$ Triton $X-100$. The nuclear pellets were counted for $5 \mathrm{~min}$

\section{LH-20 chromatography}

Aliquots of the incubation medium were chromatographed on Sephadex LH-20 (24). Iodide was eluted from the column with $4 \times 1 \mathrm{ml} 0.1$ $\mathrm{N} \mathrm{HCl}$. Subsequently, possible conjugates were eluted eight times with $1 \mathrm{ml} \mathrm{H} \mathrm{H}_{2} \mathrm{O}$, and finally, the remaining Triac or $\mathrm{T}_{3}$ was eluted from the column four times with $1 \mathrm{ml} 50 \%$ ethanol in $0.1 \mathrm{~N} \mathrm{NaOH}$.

\section{TSH release and cellular content}

After removal of the culture medium, cells were washed once with incubation medium. The culture medium was centrifuged $(2000 \times g)$, and the supernatant was frozen until hormone determination. The incubation medium was identical to the culture medium, except that fetal calf serum was replaced by $0.5 \%$ BSA. The pituitary cells were preincubated for $2 \mathrm{~h}$ at $37 \mathrm{C}$ in the absence or presence of variable concentrations ( $1 \mathrm{nM}$ to $1 \mu \mathrm{M}$ ) Triac, $\mathrm{T}_{3}$, or $\mathrm{T}_{4}$. The preincubation medium was discarded, and fresh incubation medium was added which contained $100 \mathrm{~nm}$ TRH without or with the same concentrations Triac, $\mathrm{T}_{3}$, or $\mathrm{T}_{4}$ as those described above. Incubation was continued for $2 \mathrm{~h}$ at 37 C. This medium was removed, centrifuged $(2000 \times g)$, and stored at $-20 \mathrm{C}$.

To determine the TSH content of cells, $0.5 \mathrm{ml}$ incubation medium was added to the wells. The cells were scraped from the wells with a rubber policeman, and the wells were sonicated twice for $30 \mathrm{sec}$. The extracts were removed, and the wells were washed once with $0.5 \mathrm{ml}$ medium. The two fractions were then combined (volume of cell extract, $1.0 \mathrm{ml})$ and centrifuged $(2000 \times g)$ at room temperature, and the supernatant was frozen until further analysis.

\section{TSH determination}

TSH was measured by RIA. TSH $(2 \mu \mathrm{g})$ was labeled with ${ }^{125} \mathrm{I}(1 \mathrm{mCi})$ by the lactoperoxidase method and subsequently purified on a Sephadex G-25 (medium) and a Sephadex G-100 column, as previously described (17).

\section{Free Triac and $T_{3}$ concentrations}

Calculation of the free Triac and free $T_{3}$ concentrations was based on determination of the free fractions by equilibrium dialysis (25). Determination of the free Triac fraction was corrected for the fact that only between $55-65 \%$ of [ $\left.{ }^{125} \mathrm{I}\right]$ Triac is precipitated with $\mathrm{MgCl}_{2}$.

In medium with $0.5 \% \mathrm{BSA}$, the free fractions of Triac, $\mathrm{T}_{3}$, and $\mathrm{T}_{4}$ were $0.47 \pm 0.03 \%(n=5), 3.45 \pm 0.05 \%(n=4)$, and $0.41 \pm 0.03 \%$ $(n=5)$, respectively. In rat serum, the free fractions of Triac, $T_{3}$, and $T_{4}$ were $0.028 \%, 0.381 \%$, and $0.025 \%$, respectively. The free Triac or $\mathrm{T}_{3}$ fraction in $0.5 \%$ BSA did not change after the addition of $10 \mathrm{nM}$ or $1 \mu \mathrm{M}$ unlabeled Triac.

In medium with $0.1 \%$ BSA, the free fraction of Triac was $1.84 \pm$ $0.07 \%(n=9)$. This value did not change after the addition of $10 \mathrm{~nm}$ 
Triac $(1.75 \pm 0.06 \% ; n=5)$, but it increased after the addition of $10 \mu \mathrm{M}$ Triac, $\mathrm{T}_{3}, \mathrm{~T}_{4}$, or Tetrac to $2.55 \pm 0.07 \%(\mathrm{n}=5), 2.04 \pm 0.05 \%(\mathrm{n}=3)$, $2.15 \pm 0.06 \%(n=3)$, and $2.42 \%(n=2)$, respectively. The free Triac fractions (in $0.1 \% \mathrm{BSA}$ ) in the presence of $10 \mu \mathrm{M} \mathrm{MDC}$, oligomycin, or monensin were $1.77 \pm 0.07 \%(n=5), 1.76 \pm 0.10 \%(n=5)$, and 1.83 $\pm 0.13 \%(n=5)$, respectively.

\section{ATP determination}

The cellular ATP content was determined in perchloric acid $(0.2 \mathrm{M})$ extracts with the Lumac A.E.C.-Kit (Lumac, Landgraaf, The Netherlands).

\section{Statistics}

The statistical significance of the effects of the tested compounds on $\left[{ }^{125} \mathrm{I}\right] \mathrm{Triac}$ and $\left[{ }^{125} \mathrm{I}\right] \mathrm{T}_{3}$ uptake or on TSH secretion was evaluated by oneway analysis of variance and Student's $t$ test for unpaired observations. $P<0.05$ was regarded as statistically significant.

\section{Results}

\section{TSH release during culture}

To determine whether $\mathrm{T}_{3}, \mathrm{~T}_{4}$, or Triac affected basal TSH release from cultured anterior pituitary cells, these three hormones were added at a concentration of $10 \mathrm{nM}$ to cells cultured in medium supplemented with absorbed fetal calf serum. In addition, the effects of $\mathrm{rT}_{3}(10 \mathrm{nM})$ and TRH (1 nM) were tested (Table 1). The inhibitory effect of the thyroid hormones or analogs on basal TSH secretion during 3 days of culture decreased in the order Triac $>\mathrm{T}_{3}>\mathrm{T}_{4}>\mathrm{rT}_{3}$. The presence of $1 \mathrm{nM}$ TRH almost doubled TSH release. In two separate experiments, it was found that total TSH (released into the medium plus cellular content) increased by $65 \%$ $(P<0.001)$ after culture in the presence of $1 \mathrm{~nm} \mathrm{TRH}$ (not shown).

\section{TSH release during short term exposure to $T R H$}

The effects of Triac, $\mathrm{T}_{3}$, and $\mathrm{T}_{4}$ were also compared with respect to inhibition of $\mathrm{TRH}$-induced $\mathrm{TSH}$ release during

TABLE 1. Effects of Triac, iodothyronines, and TRH on TSH release during culture of anterior pituitary cells

\begin{tabular}{|c|c|c|}
\hline \multirow{2}{*}{$\begin{array}{l}\text { Exp } \\
\text { Conditions }\end{array}$} & \multicolumn{2}{|c|}{$\begin{array}{c}\text { TSH release }(\mathrm{ng}): \\
\text { addition present during }\end{array}$} \\
\hline & 3 days of culture & Last day of culture \\
\hline Controls & $37.2 \pm 0.8(9)$ & $30.6 \pm 0.4(8)$ \\
\hline $10 \mathrm{nM} \mathrm{T}_{3}$ & $31.1 \pm 0.5(6)^{a}$ & $26.6 \pm 0.1(3)^{b}$ \\
\hline $10 \mathrm{nM} \mathrm{T}_{4}$ & $34.0 \pm 0.5(3)$ & $28.8 \pm 0.8(3)$ \\
\hline $10 \mathrm{nM}$ Triac & $28.7 \pm 1.2(3)^{a}$ & $27.4 \pm 1.6(3)^{c}$ \\
\hline $10 \mathrm{nM} \mathrm{rT}_{3}$ & $35.6 \pm 1.7(3)$ & $32.6 \pm 1.0$ \\
\hline $1 \mathrm{nM}$ TRH & $71.7 \pm 3.7(3)^{a}$ & ND \\
\hline
\end{tabular}

Data represent the mean \pm SE of three to nine observations in two independent experiments. Anterior pituitary cells (500,000 cells/well) were cultured for 3 days in culture medium containing $10 \%$ absorbed fetal calf serum. Hormones were added either at the start of culture (first column) or after 2 days of culture (last column) at the indicated concentrations. TSH in the culture medium was measured by RIA. ND, Not determined.

${ }^{a} P<0.001$ us. controls.

${ }^{b} P<0.005$.

${ }^{\mathrm{c}} P<0.01$. short (2-h) incubation experiments. As shown in Table 2, TSH release increased by around $80 \%$ after exposure to 100 nM TRH. At the same time, the cellular TSH content decreased proportionally, suggesting that TRH stimulated the release of stored TSH (not shown). The stimulating effect of TRH on TSH release was almost completely blocked by preincubation and incubation with $10 \mathrm{~nm}$ or $1 \mu \mathrm{M} \mathrm{T}_{3}$ or Triac (Table 2).

In two experiments, we compared the effects of Triac and $\mathrm{T}_{4}$ at a concentration of $25 \mathrm{~nm}$ on TRH-induced TSH release. TSH release $(4.20 \pm 0.37 \mathrm{ng} ; \mathrm{n}=9)$ was stimulated 2 -fold after exposure to $100 \mathrm{nM}$ TRH $(8.73 \pm 0.25 \mathrm{ng} ; \mathrm{n}=9 ;+108 \%$; $p<0.001$ ). After preincubation for $2 \mathrm{~h}$ with $25 \mathrm{~nm}$ Triac or $\mathrm{T}_{4}$, TSH release was $4.92 \pm 0.25 \mathrm{ng}(\mathrm{n}=6)$ and $5.96 \pm 0.49$ $\mathrm{ng}(\mathrm{n}=6)$, respectively $(0.05<P<0.10)$.

Finally, we tested within one experiment the effects of Triac, $\mathrm{T}_{3}$, and $\mathrm{T}_{4}$ on $\mathrm{TRH}$-induced $\mathrm{TSH}$ release at lower concentrations than those of the previous series. The results shown in Table 3 demonstrate that at concentrations of 1 , 2.5 , and $10 \mathrm{nM}, \mathrm{T}_{3}$ and Triac were equally potent in suppression of the TRH-induced $\mathrm{TSH}$ release. $\mathrm{T}_{4}$, however, had no significant inhibitory effect at a concentration of $2.5 \mathrm{nM}$. The effect of $\mathrm{T}_{4}$ increased with higher concentrations, and the effect of $100 \mathrm{nM} \mathrm{T}_{4}$ was approximately as large as that of 10 $\mathrm{nm} \mathrm{T}_{3}$ or Triac.

\section{Time course of $\left[{ }^{125} I\right]$ Triac and $\left[^{125} I\right] T_{3}$ uptake}

Figure 1 shows the time course of uptake of $\left[{ }^{125} \mathrm{I}\right]$ Triac (Fig. 1A) compared with that of $\left[{ }^{125} \mathrm{I}\right] \mathrm{T}_{3}$ (Fig. 1B) in cultured anterior pituitary cells. The uptake of the two isotopes was also measured in the presence of $1 \mu \mathrm{M}$ unlabeled Triac (open symbols in Fig. 1, A and B). The uptake of $\left[{ }^{125} \mathrm{I}\right]$ Triac and $\left[{ }^{125} \mathrm{I}\right]$ $\mathrm{T}_{3}$ showed a steep phase up to $1 \mathrm{~h}$ of incubation. Between 1 and $4 \mathrm{~h}$ of incubation, the uptake of $\left[{ }^{125} \mathrm{I}\right] \mathrm{T}_{3}$ showed some further increase, whereas that of $\left[{ }^{125} \mathrm{I}\right]$ Triac had reached the maximum level.

The presence of $1 \mu \mathrm{M}$ unlabeled Triac significantly reduced the uptake of both $\left[{ }^{125} \mathrm{I}\right] \mathrm{Triac}$ and $\left[{ }^{125} \mathrm{I}\right] \mathrm{T}_{3}$ at any time point,

TABLE 2. Short term effects of $T_{3}$ and Triac on TRH-induced TSH release from cultured anterior pituitary cells

\begin{tabular}{lccc}
\hline \multicolumn{1}{c}{ Exp Conditions } & $\begin{array}{c}\text { TSH } \\
\text { Release (ng) }\end{array}$ & $\begin{array}{c}\text { Stimulation } \\
(\%)\end{array}$ & $P$ \\
\hline Controls $(\mathrm{n}=12)$ & $3.37 \pm 0.07$ & & \\
$+\mathrm{TRH}(100 \mathrm{nM})(\mathrm{n}=12)$ & $6.07 \pm 0.05$ & +80 & $<0.001^{a}$ \\
& & & \\
$\mathrm{TRH}+10 \mathrm{nM} \mathrm{T}_{3}(\mathrm{n}=5)$ & $3.87 \pm 0.15$ & +15 & $<0.001^{b}$ \\
$\mathrm{TRH}+1 \mu \mathrm{M} \mathrm{T} \mathrm{T}_{3}(\mathrm{n}=6)$ & $3.05 \pm 0.09$ & -9 & $<0.001^{b}$ \\
& & & \\
TRH + $10 \mathrm{nM}$ Triac $(\mathrm{n}=9)$ & $3.42 \pm 0.06$ & +1 & $<0.001^{b}$ \\
TRH + 100 nM Triac $(\mathrm{n}=9)$ & $3.43 \pm 0.10$ & +2 & $<0.001^{b}$ \\
TRH + 1 $\mu \mathrm{M}$ Triac $(\mathrm{n}=9)$ & $3.01 \pm 0.04$ & -11 & $<0.001^{b}$ \\
\hline
\end{tabular}

Data indicate the mean \pm SE of 5-12 observations from 3 independent experiments. Anterior pituitary cells were cultured for 3 days at a density of 500,000 cells/well. The cells were preincubated for $2 \mathrm{~h}$ in the absence or presence of $T_{3}$ or Triac at concentrations of $10 \mathrm{nM}$ to $1 \mu \mathrm{M}$. Then, they were incubated with TRH $(100 \mathrm{nM})$ for $2 \mathrm{~h}$ without or with the additions indicated. TSH was measured in the incubation medium by RIA.

${ }^{a} V$ s. controls.

${ }^{b}$ Vs. TRH alone. 
TABLE 3. Comparison of the short term effects of Triac, $T_{3}$, and $\mathrm{T}_{4}$ on the TRH-induced TSH release from cultured anterior pituitary cells

\begin{tabular}{lccl}
\hline \multicolumn{1}{c}{ Exp Conditions } & $\begin{array}{c}\text { TSH release } \\
\text { (ng) }\end{array}$ & $\begin{array}{c}\text { Stimulation } \\
(\%)\end{array}$ & $P$ \\
\hline Controls (6) & $3.97 \pm 0.35$ & & \\
$+100 \mathrm{nM}$ TRH (6) & $7.24 \pm 0.22$ & +82 & $<0.001^{a}$ \\
& & & \\
TRH + 1 nM T3 (3) & $5.64 \pm 0.25$ & +42 & $<0.001^{b}$ \\
TRH + 2.5 nM T $(3)$ & $5.65 \pm 0.43$ & +42 & $<0.001^{b}$ \\
TRH + 10 nM T ${ }_{3}(3)$ & $5.50 \pm 0.13$ & +39 & $<0.001^{b}$ \\
& & & \\
TRH + 1 nM Triac (3) & $5.73 \pm 0.15$ & +44 & $<0.001^{b}$ \\
TRH + 2.5 nM Triac (3) & $5.79 \pm 0.26$ & +46 & $<0.001^{b}$ \\
TRH + 10 nM Triac (3) & $5.47 \pm 0.15$ & +38 & $<0.001^{b}$ \\
TRH + 100 nM Triac (3) & $4.96 \pm 0.12$ & +25 & $<0.001^{b, c}$ \\
& & & \\
TRH + 2.5 nM T4 (3) & $6.70 \pm 0.30$ & +69 & $\mathrm{NS}^{b}$ \\
TRH + 10 nM T $(3)$ & $6.44 \pm 0.09$ & +62 & $<0.05^{b, d}$ \\
TRH + 100 nM T (3) & $5.32 \pm 0.32$ & +34 & $<0.001^{b}$ \\
TRH + 1 $\mu \mathrm{M} \mathrm{T}_{4}(3)$ & $4.37 \pm 0.47$ & +10 & $<0.001^{b}$ \\
\hline
\end{tabular}

Data show the mean $\pm \mathrm{SE}$ of three to six observations in a single experiment. Anterior pituitary cells were cultured for 3 days at a density of 500,000 cells/well. The experiment was performed exactly as described in Table 2.

${ }^{a} V$ s. controls.

${ }^{b}$ Vs. TRH alone.

${ }^{c} P<0.05$ or less $v$. TRH plus 1 or $2.5 \mathrm{nM}$ Triac.

${ }^{d} P<0.05$ or less $v s$. TRH plus $10 \mathrm{nM}$ Triac or $10 \mathrm{nM} \mathrm{T}_{3}$.

and the effect was largest after $4 \mathrm{~h}\left[89 \%\right.$ for $\left[{ }^{125} \mathrm{I}\right]$ Triac $(P<$ $0.001 ; \mathrm{n}=6)$ and $63 \%$ for $\left[{ }^{125} \mathrm{ITT}_{3}(P<0.001 ; \mathrm{n}=6)\right]$. It is evident from the upper curves in Fig. 1, A and B, that the uptake, expressed as a percentage of the dose of $\left[{ }^{125} \mathrm{I}\right] \mathrm{T}_{3}$, was 3 -fold higher than that of $\left[{ }^{125} \mathrm{I}\right]$ Triac. One important factor that explains this difference is the different free fraction of the two isotopes in buffer with $0.5 \% \mathrm{BSA}$, i.e. $0.47 \%$ for $\left[{ }^{125} \mathrm{I}\right]$ Triac and $3.45 \%$ for $\left[{ }^{125} \mathrm{I}\right] \mathrm{T}_{3}$. By expressing the uptake data per pM free hormone, the curves presented in Fig. $1 \mathrm{C}$ were obtained, which clearly shows that the uptake of $\left[{ }^{125} \mathrm{I}\right]$ Triac was actually more than twice that of $\left[{ }^{125} \mathrm{I}\right] \mathrm{T}_{3}$.

The media from the 4-h incubations were chromatographed on LH-20 columns to determine whether $\left[{ }^{125} \mathrm{I}\right] \mathrm{T}_{3}$ or $\left.{ }^{125} \mathrm{I}\right]$ Triac was metabolized by the pituitary cells. In the media of incubations with $\left[{ }^{125} \mathrm{ITT}_{3}(\mathrm{n}=3), 99.9 \pm 3.5 \%\right.$ of the radioactivity was recovered in the iodothyronine fraction. In the media of incubations with $\left[{ }^{125} I\right]$ Triac $(n=3), 100.5 \pm$ $2.1 \%(n=3)$ was recovered in the iodothyronine fraction (not shown).

The effect of $10 \mathrm{~nm}$ unlabeled Triac on the uptake of [ $\left.{ }^{125} \mathrm{I}\right]$ Triac and $\left[{ }^{125} \mathrm{I}\right] \mathrm{T}_{3}$ was tested in incubations lasting $1 \mathrm{~h}$. Again, it can be seen in Fig. 2 that the uptake of $\left[{ }^{125} \mathrm{I}\right]$ Triac $(n=6)$ was 3 -fold greater than that of $\left.{ }^{125}{ }^{12}\right] \mathrm{T}_{3}(\mathrm{n}=6 ; P<0.001)$. The presence of $10 \mathrm{~nm}$ unlabeled Triac, which did not change the free fraction of $\left.{ }^{125} \mathrm{I}\right]$ Triac or that of $\left[{ }^{125} \mathrm{I}\right] \mathrm{T}_{3}$, reduced the uptake of $\left.{ }^{125} \mathrm{I}\right]$ Triac by $67 \%(P<0.001)$, but reduced that of $\left[{ }^{125} \mathrm{I}\right] \mathrm{T}_{3}$ by only $35 \%(P<0.001)$.

\section{Nuclear binding of $\left[{ }^{125} I\right]$ Triac and $\left[{ }^{125} I\right] T_{3}$}

To assess nuclear binding of $\mathrm{T}_{3}$ and Triac, anterior pituitary cells $\left(800,000\right.$ cells/well) were incubated for $1 \mathrm{~h}$ with $\left.{ }^{[25} \mathrm{I}\right]$ Triac or $\left[{ }^{125} \mathrm{I}_{3} \mathrm{~T}_{3}\right.$ in the absence or presence of $10 \mu \mathrm{M}$ unlabeled
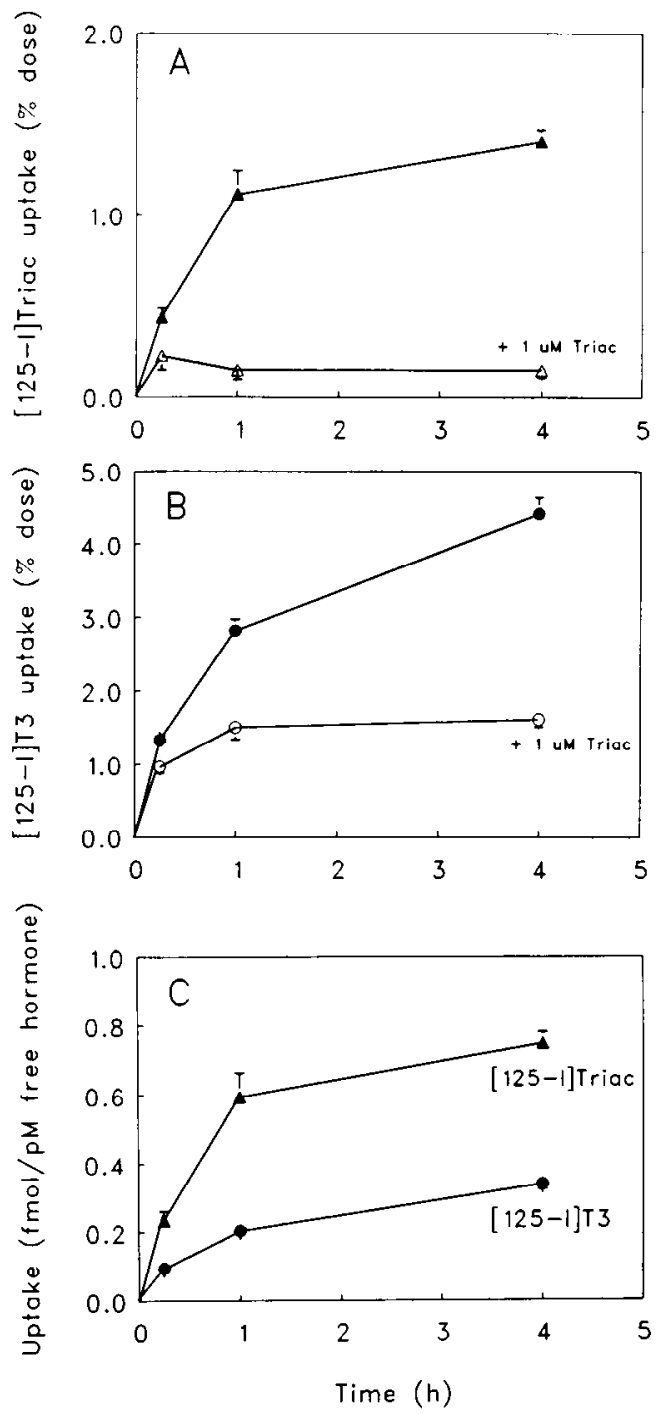

FIG. 1. Time course of uptake of $\left[{ }^{125} \mathrm{I}\right] \mathrm{Triac}(\mathrm{A})$ and $\left[{ }^{125} \mathrm{I}\right] \mathrm{T}_{3}(\mathrm{~B})$ in cultured anterior pituitary cells in the absence $(\Delta$ and $O$ ) or presence ( $\triangle$ and $O$ ) of $1 \mu \mathrm{M}$ unlabeled Triac. In $\mathrm{C}$, the uptake of $\left[{ }^{125} \mathrm{I}\right]$ Triac and $\left.{ }^{125} \mathrm{I}\right] \mathrm{T}_{3}$ is expressed per pM free hormone. Cells were cultured for 3 days at a density of 500,000 cells/well. After removal of the culture medium, they were preincubated for $30 \mathrm{~min}$ in incubation medium with $0.5 \%$ BSA. Thereafter, they were incubated in the same medium for periods of $15 \mathrm{~min}, 1 \mathrm{~h}$, or $4 \mathrm{~h}$ with $\left[{ }^{125} \mathrm{I}\right]$ Triac $(100,000 \mathrm{cpm})$ or $\left[{ }^{125} \mathrm{I}\right] \mathrm{T}_{3}$ $(50,000 \mathrm{cpm})$ without or with unlabeled Triac, as described in Materials and Methods. Data represent the mean \pm SE of six observations from two independent experiments.

Triac or $T_{3}$. To increase the free Triac fraction and, thus, the availability of isotope to the cells, $\left[{ }^{125} \mathrm{I}\right]$ Triac uptake was measured in buffer with $0.1 \%$ BSA in this experiment. As shown in the first column of Table 4, the total uptake (percentage of the dose) of $\left[{ }^{125} \mathrm{I}\right]$ Triac and $\left[{ }^{125} \mathrm{I}\right] \mathrm{T}_{3}$ under these different incubation conditions was approximately the same. Again, the presence of unlabeled Triac showed a greater inhibitory effect on the cellular uptake of $\left[{ }^{125} \mathrm{I}\right]$ Triac than on that of $\left[{ }^{125} \mathrm{I}\right] \mathrm{T}_{3}$. Also, the inhibitory effect of unlabeled $\mathrm{T}_{3}$ was greater on cellular $\left[{ }^{125} \mathrm{I}\right]$ Triac uptake than on $\left[{ }^{125} \mathrm{I}\right] \mathrm{T}_{3}$ uptake (Table 4, second column). The nuclear pellet (Table 4, third column) contained roughly the same amounts of $\left[{ }^{125} \mathrm{I}\right] \mathrm{Triac}$ 


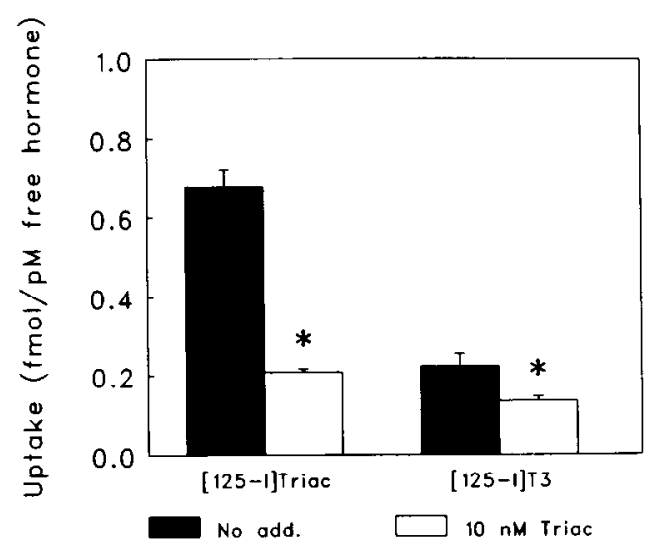

FIG. 2. Uptake of $\left[{ }^{125} \mathrm{I}\right]$ Triac and $\left[{ }^{125} \mathrm{I}\right] \mathrm{T}_{3}$ by cultured anterior pituitary cells in the absence or presence of $10 \mathrm{nM}$ unlabeled Triac. Cells were cultured for 3 days at a density of 500,000 cells/well. Preincubation ( 30 $\mathrm{min}$ ) and incubation $(60 \mathrm{~min})$ were performed as described in Fig. 1, except that half of the incubations contained $10 \mathrm{nM}$ unlabeled Triac. Bars represent the mean \pm SE of six observations from two independent experiments. *, $P<0.001,10 \mathrm{nM}$ Triac us. no additions.

TABLE 4. Total and nuclear binding of $\left[{ }^{125} \mathrm{I}\right]$ Triac and $\left[{ }^{125} \mathrm{I}\right] \mathrm{T}_{3}$ in cultured anterior pituitary cells

\begin{tabular}{lccc}
\hline \multirow{2}{*}{ Exp Conditions } & \multicolumn{3}{c}{$\left[{ }^{125} \mathrm{~T}\right]$ Radioactivity (\% dose) } \\
\cline { 2 - 4 } & Total uptake & Cell pellet & Nuclear pellet \\
\hline$\left.{ }^{125} \mathrm{I}\right]$ Triac & 4.87 & 2.67 & 0.84 \\
$+10 \mu \mathrm{M} \mathrm{Triac}$ & 1.41 & 0.52 & 0.02 \\
$+10 \mu \mathrm{M} \mathrm{T} \mathrm{T}_{3}$ & 1.32 & 0.50 & 0.02 \\
& & & \\
${ }^{125} \mathrm{I}_{3}$ & 4.40 & 2.31 & 0.70 \\
$+10 \mu \mathrm{M}$ Triac & 3.07 & 1.17 & 0.03 \\
$+10 \mu \mathrm{M} \mathrm{T}$ & 2.39 & 0.96 & 0.05 \\
\hline
\end{tabular}

Data show the means of triplicate observations in a single experiment. Anterior pituitary cells were cultured for 3 days at a density of 800,000 cells/well. Preincubation $(30 \mathrm{~min})$ and incubation $(1 \mathrm{~h})$ for determination of $\left.{ }^{125} \mathrm{I}\right]$ Triac uptake $(200,000 \mathrm{cpm})$ were carried out in medium with $0.1 \% \mathrm{BSA}$, and for determination of $\left[{ }^{125} \mathrm{I}\right] \mathrm{T}_{3}$ uptake $(100,000 \mathrm{cpm})$ in medium with $0.5 \%$ BSA. Unlabeled Triac or $\mathrm{T}_{3}(10$ $\mu \mathrm{M})$ was only present during incubation. Total uptake was measured in cells scraped from the wells in $1 \mathrm{ml}$ PBS. After centrifugation of the suspension, a cell pellet was obtained and counted. The nuclear pellet was obtained after treatment with Triton X-100 (for further details, see Materials and Methods).

and $\left[{ }^{125} \mathrm{I}_{\mathrm{T}}\right.$ after $1 \mathrm{~h}(31 \%$ and $30 \%$ of the radioactivity in the cell pellets, respectively), and the nuclear binding of $\left[{ }^{125} \mathrm{I}\right]$ Triac or $\left[{ }^{125} \mathrm{I}\right] \mathrm{T}_{3}$ was almost completely blocked by simultaneous incubation with unlabeled Triac or $\mathrm{T}_{3}$. Relative to the free fraction in the incubation medium, the nuclear uptake of $\left[{ }^{125} \mathrm{I}\right]$ Triac was about twice that of $\left[{ }^{125} \mathrm{I}\right] \mathrm{T}_{3}(0.84 \%$ dose with a free fraction of $1.84 \%$ for $\left[{ }^{125} \mathrm{I}\right] \mathrm{Triac}$ and $0.70 \%$ dose with a free fraction of $3.45 \%$ for $\left.\left[{ }^{125}\right]\right] \mathrm{T}_{3}$ ).

\section{Plasma membrane uptake of $\left[{ }^{125}\right.$ I]Triac}

To evaluate the uptake of $\left[{ }^{125} I\right]$ Triac at the level of the pituitary plasma membrane, experiments were performed in a manner similar to that previously described for $\left[{ }^{125} \mathrm{I}\right] \mathrm{T}_{3}$ and $\left[{ }^{125}\right]^{1} \mathrm{~T}_{4}$ with $15 \mathrm{~min}$ of incubation $(17,18)$. With $0.5 \%$ BSA in the medium, the 15-min uptake of $\left[{ }^{125}\right.$ I]Triac amounted to $0.46 \pm 0.04 \%$ dose $(n=8)$, and with $0.1 \%$ BSA in the medium, it was $1.70 \pm 0.06 \%$ dose $(n=8)(P<0.001)$. Corrected for the free hormone concentration, the 15-min $\left[{ }^{125} \mathrm{I}\right]$ Triac uptake in $0.5 \%$ BSA was $0.245 \pm 0.021 \mathrm{fmol} / \mathrm{pM}$ free Triac $(n=8)$, and that in $0.1 \%$ BSA was $0.231 \pm 0.008$ $\mathrm{fmol} / \mathrm{pM}$ free Triac $(\mathrm{n}=8 ; P=\mathrm{NS})$. Therefore, the 15 -min uptake experiments were performed in medium with $0.1 \%$ BSA.

Figures 3 and 4 show the results of four experiments, in which the competitive effects of various concentrations of unlabeled Triac, $\mathrm{T}_{3}, \mathrm{~T}_{4}$, or Tetrac were tested. The presence of $10 \mathrm{~nm}$ Triac resulted in significantly lower uptake of $\left[{ }^{125} \mathrm{I}\right]$ Triac $(35 \% ; P<0.001)$, whereas $10 \mu \mathrm{M}$ Triac produced a maximal inhibitory effect of $56 \%(P<0.001$; Fig. 3). A similar inhibitory effect on $\left[{ }^{125} \mathrm{I}\right]$ Triac uptake was obtained in the presence of $10 \mu \mathrm{M} \mathrm{T}_{3}, \mathrm{~T}_{4}$, or Tetrac (Fig. 4). When [ $\left.{ }^{125} \mathrm{I}\right] \mathrm{T}_{3}$ uptake was measured in the presence of $10 \mu \mathrm{M} \mathrm{T}, \mathrm{T}_{4}$, Triac, or Tetrac, uptake was reduced by $70 \%, 60 \%, 47 \%$, and $48 \%$,

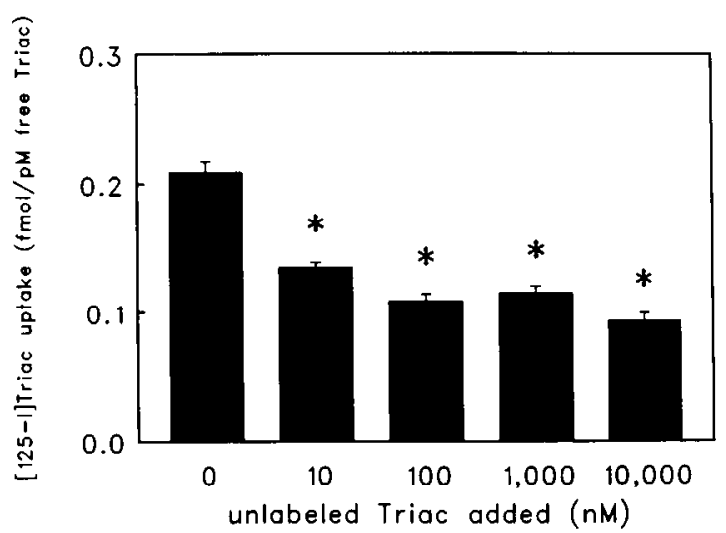

Fig. 3. Effects of increasing concentrations unlabeled Triac on the 15min uptake of $\left[{ }^{125} \mathrm{I}\right] \mathrm{Triac}$ in cultured anterior pituitary cells. Cells were cultured for 3 days at a density of 500,000 cells/well. After removal of the culture medium, they were preincubated for $30 \mathrm{~min}$ in medium containing $0.1 \% \mathrm{BSA}$. This was followed by incubation for $15 \mathrm{~min}$ in the same medium, with [ ${ }^{125}$ I]Triac $(100,000 \mathrm{cpm})$ and unlabeled Triac added at concentrations of $10 \mathrm{nM}$ to $10 \mu \mathrm{M}$. Bars represent the mean \pm SE of six to eight observations from two independent experiments. ${ }^{*}, P$ $<0.001$ vs. no additions.

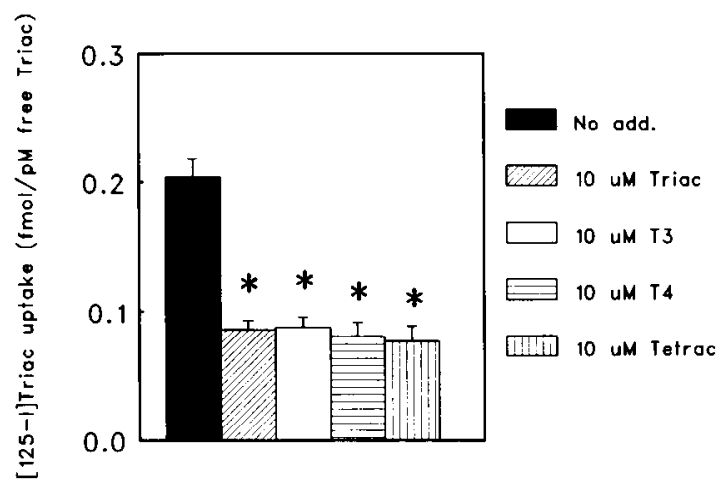

Fig. 4. Effects of Triac, $T_{3}, T_{4}$, and Tetrac on the 15 -min uptake of $\left.{ }^{[25} \mathrm{I}\right]$ Triac in cultured anterior pituitary cells. Cells were cultured for 3 days at a density of 500,000 cells/well. Experiments were performed as described in Fig. 3, without or with $10 \mu \mathrm{M}$ Triac, $\mathrm{T}_{3}, \mathrm{~T}_{4}$, or Tetrac present during the incubation. Bars represent the mean \pm SE of six to nine observations from three independent experiments. ${ }^{*}, P<0.001$ vs. no additions. 
respectively (all $P<0.001$ ).

Preincubation and incubation with MDC, oligomycin, and monensin, can be used to study the possible involvement of receptor-mediated endocytosis, energy dependence, and the dependence of the uptake process on the $\mathrm{Na}^{+}$gradient, respectively $(17,18)$. When tested at a concentration of 10 $\mu \mathrm{M}, \mathrm{MDC}$ reduced the 15 -min uptake of $\left[{ }^{125} \mathrm{I}\right]$ Triac by $19 \%$ $(\mathrm{n}=11 ; P<0.005)$, oligomycin reduced it by $23 \%(\mathrm{n}=11$; $P<0.001)$, and monensin reduced it by $15 \%(\mathrm{n}=11 ; P<$ 0.005 ; Fig. 5).

Finally, the 15-min uptake of $\left[{ }^{125} \mathrm{I}\right] \mathrm{Triac}$ was directly compared with that of $\left[{ }^{125} \mathrm{l}\right] \mathrm{T}_{3}$ with respect to the energy dependence and temperature dependence of the uptake process. Under control conditions, the uptake of $\left.{ }^{125} \mathrm{I}\right] \mathrm{T}_{3}$ amounted to $1.55 \pm 0.05 \%$ dose $(n=9)$, and that of $\left[{ }^{125} \mathrm{I}\right]$ Triac was $1.50 \pm$ $0.05 \%$ dose $(\mathrm{n}=11$; Fig. 6 , first and third columns). Expressed per pM free hormone, the uptake of $\left[{ }^{125} \mathrm{I}\right] \mathrm{T}_{3}$ was $0.112 \pm$ $0.004(n=9)$, and that of $\left[{ }^{125} \mathrm{I}\right]$ Triac was $0.204 \pm 0.006 \mathrm{fmol}$ $(\mathrm{n}=11 ; P<0.001)$. Preincubation and incubation with 10 $\mu \mathrm{M}$ oligomycin reduced the cellular ATP content by $51 \%$ ( $P$ $<0.001$; Fig. 6 , last two columns). At the same time, the uptake of $\left[{ }^{125} \mathrm{I}_{\mathrm{T}} \mathrm{T}_{3}\right.$ was reduced by $77 \%(P<0.001)$, and that of $\left[{ }^{125}\right.$ I]Triac by $25 \%(P<0.001)$. On the other hand, the temperature dependences of the two uptake processes were comparable. At $0 \mathrm{C}$, uptake of $\left[{ }^{125} \mathrm{I}\right]$ Triac was $0.19 \pm 0.04 \%$ dose $(n=6)$, and that of $\left[{ }^{125} I\right] \mathrm{T}_{3}$ was $0.11 \pm 0.03 \%$ dose $(n$ $=6)$. Both increased 5 -fold when the temperature was increased to $\left.22 \mathrm{C}:{ }^{125} \mathrm{I}\right]$ Triac uptake, $0.89 \pm 0.02 \%$ dose $(\mathrm{n}=$ 6); $\left[{ }^{125} \mathrm{I}\right] \mathrm{T}_{3}$ uptake, $0.80 \pm 0.04 \%$ dose $(\mathrm{n}=6)$. When the temperature was raised from 22 to $37 \mathrm{C}$, the uptake of the two isotopes increased 2-fold: $\left[{ }^{125} \mathrm{I}\right]$ Triac uptake, $1.76 \pm$ $0.06 \%$ dose $(n=6) ;\left[{ }^{125} \mathrm{I}\right] \mathrm{T}_{3}$ uptake, $1.71 \pm 0.04 \%$ dose $(\mathrm{n}=$ 6).

\section{Discussion}

The results of the present study demonstrate that $\left[{ }^{125} \mathrm{I}\right]$ Triac is rapidly taken up by the pituitary. At comparable free medium concentrations (Triac, 0.6-2.2 $\mathrm{pM}^{2} \mathrm{~T}_{3}, 1.7 \mathrm{pM}$ ), both cellular and nuclear uptakes of $\left[{ }^{125} \mathrm{I}\right]$ Triac were at least twice

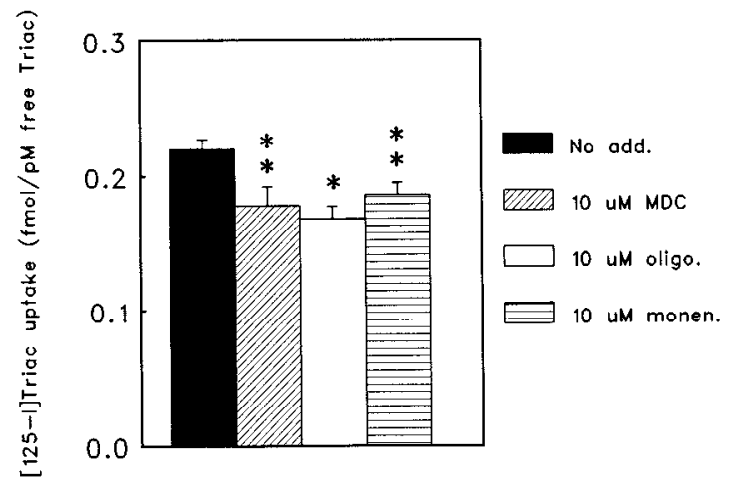

FIG. 5. Effects of MDC, oligomycin, and monensin on the 15-min uptake of $\left[{ }^{125} \mathrm{I}\right]$ Triac in cultured anterior pituitary cells. Cells were cultured for 3 days at a density of 500,000 cells/well. Preincubation ( 30 $\mathrm{min}$ ) and incubation (15 min) were performed as described in Fig. 3, except that MDC, oligomycin, and monensin $(10 \mu \mathrm{M})$ were present during preincubation and incubation. Bars represent the mean $\pm \mathrm{SE}$ of 11 observations from 4 independent experiments. ${ }^{*}, P<0.001 ;{ }^{* *}, P<$ 0.005 (vs. no additions).

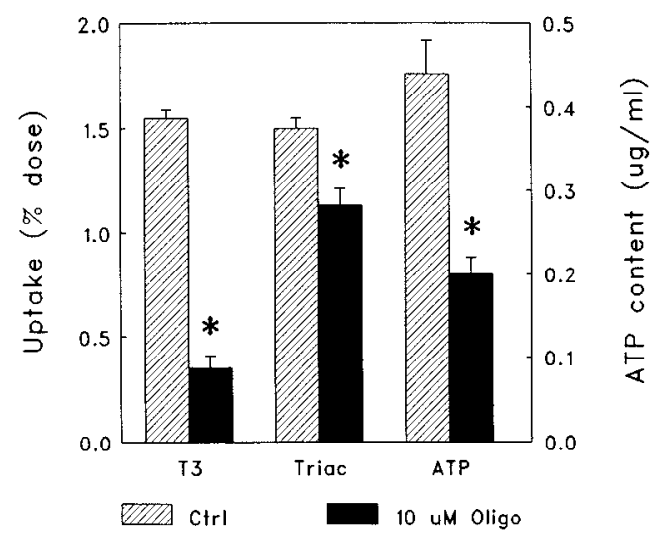

FIG. 6. Effects of oligomycin on the 15 -min uptake of $\left[{ }^{125} \mathrm{I}\right] \mathrm{T}_{3}$ and $\left[{ }^{125} \mathrm{I}\right]$ Triac and on ATP contents of cultured anterior pituitary cells. Anterior pituitary cells were cultured for 3 days at a density of 500,000 cells/ well. Cells were preincubated for $30 \mathrm{~min}$ without or with $10 \mu \mathrm{M}$ oligomycin. Uptake experiments were performed for $15 \mathrm{~min}$ with $\left[{ }^{125} \mathrm{I}\right]$ $\mathrm{T}_{3}(50,000 \mathrm{cpm} /$ well in medium with $0.5 \% \mathrm{BSA})$ or $\left[{ }^{125} \mathrm{I}\right] \mathrm{Triac}(100,000$ $\mathrm{cpm} /$ well in medium with $0.1 \% \mathrm{BSA}$ ) without or with $10 \mu \mathrm{M}$ oligomycin present. Cells used for determination of ATP content were preincubated and incubated without or with $10 \mu \mathrm{M}$ oligomycin, but without tracer. Bars show the mean \pm SE of 9-14 observations from 6 experiments. ${ }^{*}, P<0.001$ vs. controls.

those of $\left[{ }^{125} \mathrm{I}\right] \mathrm{T}_{3}$. Furthermore, Triac was, on the basis of the free hormone concentration, more effective than $\mathrm{T}_{3}$ or $\mathrm{T}_{4}$ in suppression of basal and TRH-induced TSH release.

These comparisons were made in anterior pituitary cells in vitro, i.e. an experimental system in which differences in the MCR do not play a role, and neither $\left[{ }^{125} \mathrm{I}\right]$ Triac nor $\left[{ }^{125} \mathrm{I}\right] \mathrm{T}_{3}$ was metabolized. On the other hand, the cells showed metabolic activity, because they were previously shown to deiodinate around $20 \%$ of cellular $\left[{ }^{125} \mathrm{I}\right] \mathrm{T}_{4}$ to $\left[{ }^{125} \mathrm{I}\right] \mathrm{T}_{3}$ in $24 \mathrm{~h} \mathrm{(18)}$.

In the 2-h incubation experiments with TRH, Triac was, on the basis of the total hormone concentration, equally potent as $\mathrm{T}_{3}$ in suppression of the TRH-induced TSH release. To obtain a similar effect with $\mathrm{T}_{4}$, at least a 10 -fold higher total dose was required compared to Triac or $\mathrm{T}_{3}$. However, when the difference in the free fractions of Triac, $\mathrm{T}_{3}$, and $\mathrm{T}_{4}$ is taken into account (ratio of the free fractions, 1:8:1), the order of potency for inhibition of TRH-induced TSH release appears to be Triac $>T_{3}>T_{4}$. A significant reduction of the TSH response to TRH was seen with concentrations as low as $1 \mathrm{~nm}$ Triac or $\mathrm{T}_{3}$. The anterior pituitary cell preparation may be more sensitive to demonstrate these effects than superfused pituitary fragments (16). In the latter system, 100 nM Triac or $\mathrm{T}_{3}$ (in medium with $0.25 \% \mathrm{BSA}$ ) was required to significantly reduce the TSH response to TRH.

It has been demonstrated in vivo that $\mathrm{T}_{3}$ or $\mathrm{T}_{4}$ injected into hypothyroid rats reduced the plasma TSH level within $2 \mathrm{~h}$ (26). This effect was related to nuclear binding of $T_{3}(26)$ and probably reflects interference with the TSH release process. On the other hand, when pituitary cells were exposed for a prolonged period of time (1-3 days during culture) to Triac, $\mathrm{T}_{3}, \mathrm{~T}_{4}$, or TRH, the results were more likely to reflect interference with TSH synthesis. This idea was supported by the finding that the total TSH (medium plus cells) was significantly increased after culture in the presence of $1 \mathrm{nM}$ TRH, suggesting de novo TSH synthesis, which confirmed the early 
results of Vale et al. (27).

Triac seemed to be the most effective in suppression of TSH release during culture. Addition of the same total concentration of $\mathrm{T}_{4}(10 \mathrm{nM})$ showed a smaller effect on TSH release than that obtained with $T_{3}$ or Triac after both 1 and 3 days of culture. When it is taken into account that in medium with $10 \%$ serum, the free Triac fraction is much lower than that of $\mathrm{T}_{3}$, Triac is the most effective in inhibition of TSH synthesis. This was also observed in thyrotropic tumor cells cultured in the presence of serum, when thyroid hormones or analogs were added for $24 \mathrm{~h}$ (15). In that study, $\mathrm{T}_{3}$ and Triac were equally potent when total hormone concentrations were compared, and both showed a 10-fold higher potency than $T_{4}$.

Both cellular and nuclear uptakes per pm free hormone of $\left[{ }^{125} \mathrm{I}\right]$ Triac were twice those of $\left[{ }^{125} \mathrm{I}\right] \mathrm{T}_{3}$. Studies with nuclei isolated from thyrotropic tumor cells, pituitary tumor cells, normal rat liver, or heart demonstrated an equal or even higher potency of Triac compared to $\mathrm{T}_{3}$ to displace nuclear $\left[{ }^{125} \mathrm{I}\right] \mathrm{T}_{3}$ binding $(15,28-30)$, indicating a high affinity for Triac of the thyroid hormone receptor.

The initial rate of ${ }^{125}$ I]Triac uptake per pM free hormone measured over $15 \mathrm{~min}$ was twice that of $\left[{ }^{125} \mathrm{I}\right] \mathrm{T}_{3}$. The latter was previously shown to be as high as that of $\left[{ }^{125} \mathrm{I}\right] \mathrm{T}_{4}(18)$. The 15-min [ $\left.{ }^{125} I\right]$ Triac uptake was reduced by simultaneous incubation with unlabeled Triac at concentrations as low as $10 \mathrm{nM}$, suggesting the existence of a carrier in the pituitary cell membrane. Apparently, this carrier also recognized $\mathrm{T}_{3}$, $\mathrm{T}_{4}$, and Tetrac, as each of these substances reduced $\left[{ }^{125} \mathrm{I}\right] \mathrm{Triac}$ uptake to the same extent as Triac when added at a concentration of $10 \mu \mathrm{M}$.

The experiments with oligomycin showed that the uptake of $\left.{ }^{125} \mathrm{I}\right]$ Triac was only partially dependent on the cellular energy status; the effect of oligomycin on the uptake of $\left[{ }^{125} \mathrm{I}\right]$ Triac was only $50 \%$ of that on the uptake of $\left[{ }^{125} 1\right] \mathrm{T}_{3}$. Furthermore, the experiments with monensin indicate that the uptake process was not strictly dependent on the $\mathrm{Na}^{+}$gradient. Compared with our previous observations on the effect of monensin on the uptake of $\left.{ }^{125} \mathrm{I}\right] \mathrm{T}_{3}$ or $\left[{ }^{125} \mathrm{I}\right] \mathrm{T}_{4}(\sim 40 \%)(17$, $18)$, the effect on the uptake of $\left.{ }^{125} \mathrm{I}\right] \mathrm{Triac}$ was much smaller. The same conclusion holds for the effect of MDC. Part of this difference might be due to the fact that the data were not corrected for nonspecific uptake of $\left[{ }^{125} \mathrm{I}\right] \mathrm{Triac}$ or $\left[{ }^{125} \mathrm{I}\right] \mathrm{T}_{3}$, and that the nonspecific uptake of $\left.{ }^{125} \mathrm{I}\right]$ Triac might have been larger than that of $\left.{ }^{125} \mathrm{I}\right] \mathrm{T}_{3}$. On the other hand, the temperature dependence of the uptake of $\left[{ }^{125} \mathrm{I}\right] \mathrm{Triac}$ and $\left[{ }^{125} \mathrm{I}\right] \mathrm{T}_{3}$ was the same.

Together, our results suggest that $\left[{ }^{125} \mathrm{I}\right]$ Triac is taken up by pituitary cells by a carrier-mediated mechanism that is influenced to only a minor extent by the cellular energy status or the $\mathrm{Na}^{+}$gradient. [ ${ }^{125} \mathrm{I}$ ] Triac uptake, expressed per pM free hormone was twice as high as that of $\left.{ }^{125}{ }^{12}\right] \mathrm{T}_{3}$. Nevertheless, the uptake mechanism for Triac shared some properties with the transport of $T_{3}$ (and $T_{4}$ ). This could mean that Triac is partly taken up by the anterior pituitary by the same transport mechanism as that for $T_{3}$ and $T_{4}$ and partly by another transport system.

When Triac is used to suppress TSH secretion in patients, it has to be administered in relatively large doses (9-11) due to its short half-life $(\sim 6 \mathrm{~h})(7)$. This idea is supported by the observation that dividing the daily Triac dose into four parts had a more pronounced effect on serum TSH in euthyroid subjects than a single dose (8). One of the factors that could explain the short half-life of Triac in humans is the recent finding that Triac is extremely rapidly glucuronidated in the liver (31).

It was recently suggested that Triac might be of importance in the euthyroid sick syndrome (3-5). This syndrome is characterized by low serum $T_{3}$ and $T_{4}$ levels without a rise in serum TSH (32). The normal serum level of Triac is about $50 \mathrm{pm}$ (2) compared to a normal serum $\mathrm{T}_{3}$ level of $2000 \mathrm{pm}$ (26). As the free fraction of Triac in serum is much lower than that of $T_{3}(33)$, the difference in free hormone concentration in normal subjects may be a factor of 400 . During the euthyroid sick syndrome, the serum $\mathrm{T}_{3}$ level may drop as much as $50 \%$, with a concomitant decrease in the free $\mathrm{T}_{3}$ concentration (32). In contrast to $T_{3}$, Triac is strongly bound to prealbumin in serum, and the prealbumin level decreases substantially during illness (5), leading to a rise in the free Triac fraction (3- to 9-fold) (Everts, M. E., and T. J. Visser, unpublished). This effect should be added to an increased Triac production, whereas deiodination of $T_{4}$ to $T_{3}$ is diminished $(3,4)$. Together with our observations that the thyrotroph seems to be more sensitive to Triac than to $T_{3}$ and the fact that the uptake of Triac is higher than that of $\mathrm{T}_{3}$, it is possible that Triac plays a role in the control of TSH secretion in the euthyroid sick syndrome.

\section{Acknowledgment}

The material used in the TSH assay was kindly provided by the National Hormone and Pituitary Program of the NIDDK (Bethesda, MD).

\section{References}

1. Gavin LA, Hammond ME, Castle IN, Cavalieri RR 1978 3,3'Diiodothyronine production, a major pathway of peripheral iodothyronine metabolism in man. J Clin Invest 61:1276-1285

2. Gavin LA, Livermore BM, Cavalieri RR, Hammond ME, Castle IN 1980 Serum concentration, metabolic clearance, and production rates of 3,5,3'-triiodothyroacetic acid in normal and athyreotic man. J Clin Endocrinol Metab 51:529-534

3. Dlott RS, LoPresti JS, Nicoloff JT 1992 Evidence that triiodothyroacetate (triac) is the autocrine thyroid hormone in man. Thyroid [Suppl 1] 2:S-94 (Abstract)

4. LoPresti JS, Dlott RS 1992 Augmented conversion of $T_{3}$ to triac (T3AC) is the major regulator of the low $\mathrm{T}_{3}$ state in fasting man. Thyroid [Suppl 1] 2:S-39 (Abstract)

5. Carlin K, Carlin S 1993 Possible etiology for euthyroid sick syndrome. Med Hypotheses 40:38-43

6. Medeiros-Neto G, Kallas WG, Knobel M, Cavaliere H, Matar E 1980 Triac $\left(3,5,3^{\prime}\right.$-triiodothyroacetic acid) partially inhibits the thyrotropin response to synthetic thyrotropin-releasing hormone in normal and thyroidectomized hypothyroid patients. J Clin Endocrinol Metab 50:223-225

7. Menegay C, Juge C, Burger AG 1989 Pharmacokinetics of 3,5,3'triiodothyroacetic acid and its effects on serum TSH levels. Acta Endocrinol (Copenh) 121:651-658

8. Bracco D, Morin O, Schutz $Y$, Liang $H$, Jequier E, Burger AG 1993 Comparison of the metabolic and endocrine effects of $3,5,3^{\prime}$. 
triiodothyroacetic acid and thyroxine. J Clin Endocrinol Metab 77:221-228

9. Beck-Peccoz P, Sartorio A, De Medici C, Grugni G, Morabito F, Faglia G 1988 Dissociated thyromimetic effects of 3,5,3' -triodothyroacetic acid (Triac) at the pituitary and peripheral tissue levels. J Endocrinol Invest 11:113-118

10. Mueller-Gaertner HW, Schneider C 1988 3,5,3' '-Triiodo-thyroacetic acid minimizes the pituitary thyrotropin secretion in patients on levo-thyroxine therapy after ablative therapy for differentiated thyroid carcinoma. Clin Endocrinol (Oxf) 28:345-351

11. Mechelany C, Schlumberger M, Challeton C, Comoy E, Parmentier C 1991 Triac (3,5,3' -triiodothyroacetic acid) has parallel effects at the pituitary and peripheral tissue levels in thyroid cancer patients treated with L-thyroxine. Clin Endocrinol (Oxf) 35:123-128

12. Salmela PI, Wide L, Juustila H, Ruokonen A 1988 Effects of thyroid hormones $\left(\mathrm{T}_{4}, \mathrm{~T}_{3}\right)$, bromocriptine and triac on inappropriate TSH hypersecretion. Clin Endocrinol (Oxf) 28:497-507

13. Kunitake JM, Hartman $\mathbf{N}$, Henson LC, Lieberman J, Williams DE, Wong M, Hershman JM 1989 3,5,3'-Triiodothyroacetic acid therapy for thyroid hormone resistance. J Clin Endocrinol Metab 69:461-466

14. Sherman SI, Ladenson PW 1992 Organ-specific effects of tiratricol: a thyroid hormone analog with hepatic, not pituitary, superagonist effects. J Clin Endocrinol Metab 75:901-905

15. Gershengorn M, Geras E, Marcus-Samuels BE, Rebecchi MJ 1979 Receptor affinity and biological potency of thyroid hormones in thyrotropic cells. Am J Physiol 237:E142-E146

16. Szabolcs I, Schultheiss H, Astier H, Horster FA 1991 Effects of triiodothyronine, triiodothyroacetic acid, iopanoic acid and iodide on the thyrotropin-releasing hormone-induced thyrotropin release from superfused rat pituitary fragments. Acta Endocrinol (Copenh) 125:427-434

17. Everts ME, Docter R, van Buuren JCJ, van Koetsveld PM, Hofland LJ, de Jong M, Krenning EP, Hennemann G 1993 Evidence for carrier-mediated uptake of triiodothyronine in cultured anterior pituitary cells of euthyroid rats. Endocrinology 132:1278-1285

18. Everts ME, Docter $R$, Moerings EPCM, van Koetsveld PM, Visser TJ, de Jong M, Krenning EP, Hennemann G 1994 Uptake of thyroxine in cultured anterior pituitary cells of euthyroid rats. Endocrinology 134:2490-2497

19. Yan Z, Hinkle PM 1993 Saturable, stereospecific transport of 3,5,3' triiodo-L-thyronine and L-thyroxine into $\mathrm{GH}_{4} \mathrm{C}_{1}$ pituitary cells. J Biol Chem 268:20179-20184

20. Rutgers M, Heusdens FA, Visser TJ 1989 Metabolism of triiodothyroacetic acid $\left(\mathrm{TA}_{3}\right)$ in rat liver. I. Deiodination of $\mathrm{TA}_{3}$ and $\mathrm{TA}_{3}$ sulfate by microsomes. Endocrinology 125:424-243
21. Oosterom R, Verleun T, Lamberts SWJ 1983 Basal and dopamineinhibited prolactin secretion by anterior pituitary cells: effects of culture conditions. Mol Cell Endocrinol 29:197-212

22. Oosterom R, Verleun T, Zuyderwijk J, Lamberts SWJ 1983 Growth hormone secretion by cultured rat anterior pituitary cells. Effects of culture conditions and dexamethasone. Endocrinology 113:735-741

23. Movius EG, Phyillaier MM, Robbins J 1989 Phloretin inhibits cellular uptake and nuclear receptor binding of triiodothyronine in human Hep G2 hepatocarcinoma cells. Endocrinology 124:19881997

24. Docter R, Krenning EP, Bernard HF, Visser TJ, Hennemann G 1988 Inhibition of uptake of thyroid hormone into rat hepatocytes by preincubation with $N$-bromoacetyl-3,3',5-triiodothyronine. Endocrinology 123:1520-1525

25. Sterling K, Brenner MA 1966 Free thyroxine in human serum: simplified measurement with the aid of magnesium precipitation. J Clin Invest 45:153-163

26. Larsen PR, Silva JE 1983 Intrapituitary mechanisms in the control of TSH secretion. In: Oppenheimer JH, Samuels HH (eds) Molecular Basis of Thyroid Hormone Action. Academic Press, New York, pp 351-385

27. Vale W, Grant G, Amoss M, Blackwell R, Guillemin R 1972 Culture of enzymatically dispersed anterior pituitary cells: functional validation of a method. Endocrinology 91:562-572

28. Samuels HH, Stanley F, Casanova J 1979 Relationship of receptor affinity to the modulation of thyroid hormone nuclear receptor levels and growth hormone synthesis by L-triiodo-thyronine and iodothyronine analogues in cultured $\mathrm{GH}_{1}$ cells J Clin Invest 63:12291240

29. Oppenheimer JH, Schwartz HL, Dillman W, Surks MI 1973 Effect of thyroid hormone analogues on the displacement of $I^{125} \mathrm{~L}$-triiodothyronine from hepatic and heart nuclei in vivo: possible relationship to biological activity. Biochem Biophys Res Commun 55:544-550

30. DeGroot LJ, Strausser JL 1974 Binding of $T_{3}$ in rat liver nuclei. Endocrinology 95:74-83

31. Moreno M, Kaptein E, Goglia F, Visser TJ, Rapid glucuronidation of tri- and tetraiodothyroacetic acid to ester glucuronides in human liver and to ether glucuronides in rat liver. Endocrinology, in press

32. Docter R, Krenning EP, De Jong M, Hennemann G 1993 The sick euthyroid syndrome: changes in thyroid hormone serum parameters and hormone metabolism. Clin Endocrinol (Oxf) 39:499-518

33. Christensen LK 1960 The binding to serum protein of acetic and propionic acid analogues of thyroxine and triiodothyronine. Endocrinology $67: 407-412$ 